\title{
A Synopsis of US Consumer Perception of Genetically Modified (Biotech) Crops ${ }^{1}$
}

\author{
Edward A. Evans and Fredy H. Ballen²
}

\section{Introduction}

Over the last few decades, the use of modern tools of molecular biology has made it possible to discover, isolate, and introduce several important agricultural traits (useful to both farmers and consumers) in cultivated crops. Such improvements are usually accomplished by the technique known as genetic engineering. Genetic engineering $(\mathrm{GE})$, also known as genetic modification (GM), is the process by which an organism's genome (the entirety of an organism's hereditary information) is deliberately modified by inserting, altering, and/or isolating a specific segment of DNA that contains a gene or genes of interest, with the aim of introducing a new trait or suppressing an undesirable one. Crops obtained by using GE techniques are also commonly known as Genetically Modified (GM) crops, or biotech crops. The main advantage of the application of this technique is that it greatly shortens the time of crop development and improves the certainty of the outcome, compared with conventional crop development methods such as crop breeding.

To date, there are more than 30 commercial GM crops grown on almost 160 million hectares of land in 29 countries. Moreover, it is expected that by 2015 , there will be more than 120 GM crops (Stein and RodriguezCerezo 2010; James 2008). Benefits associated with such improved crops include resistance to pests and diseases; tolerance towards herbicides, drought, salinity, and extreme temperatures; and improved nutritional and grain quality.

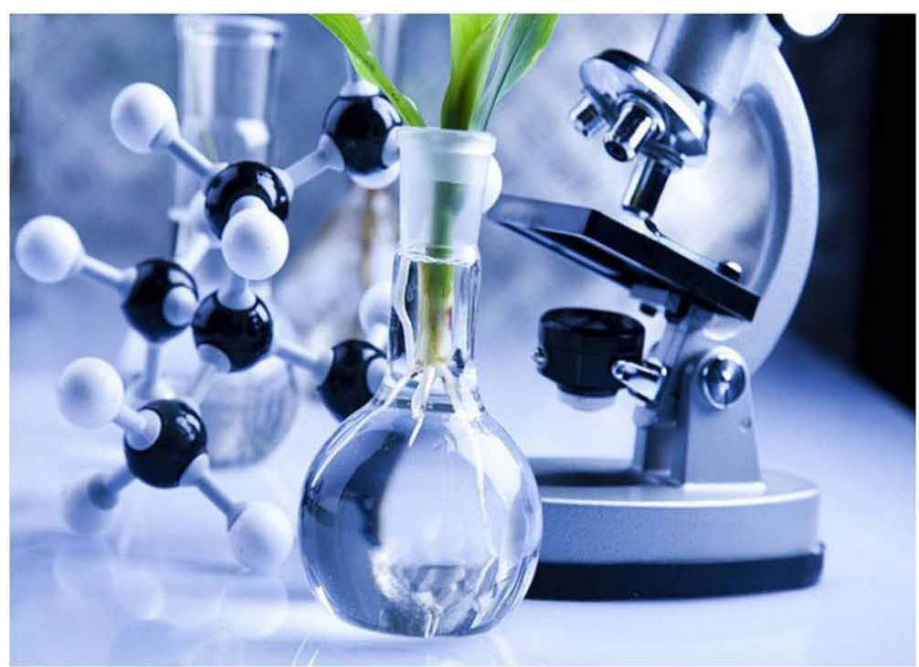

Credits: ipsnews.net

Genetically modified crops have societal and environmental benefits, such as higher revenues; more agricultural productivity; fewer pesticides and herbicides; and improved soil management practices, such as the no-till farming system (Brookes and Barfoot 2010).

Despite the fact that GM crops are widely grown, public opinion is mixed. While the European Union (EU) is very critical of GM crops, most of the other countries are either indifferent or favor GM and related products (products derived from GM ingredients) (Stein and Rodriguez-Cerezo 2010). Genetic modification crop research continues to

1. This is EDIS document FE934, a publication of the Food and Resource Economics Department, Florida Cooperative Extension Service, Institute of Food and Agricultural Sciences, University of Florida, Gainesville, FL. Published June 2013. Please visit the EDIS website at http://edis.ifas.ufl.edu.

2. Edward A. Evans, assistant professor, Food and Resource Economics Department, University of Florida, Tropical Research and Education Center, Homestead, FL, and Fredy H. Ballen, economic analysis coordinator II, University of Florida, Tropical Research and Education Center, Homestead, FL. 
be important. For example, the University of Florida is in the final stage of developing and commercializing a GM papaya that is resistant to papaya ringspot disease (PRSV) disease (a major limiting factor to improved productivity and profitability of papaya production in South Florida see EDIS FE918). The aim of this article is to provide an update on recent developments with respect to GM food crops, as well as an assessment of US public opinion with regards to GM foods in general. A successful case of how a US-grown GM crop gained acceptance in one of the strictest fruit importing countries is presented. In the absence of any formal interviews carried out by the authors, the information presented in this document relies exclusively on secondary sources obtained through desk research.

\section{Classification of GM Research}

Research on the development of GM crops can be categorized into first, second, or third generation (Panos 1999). First-generation GM crops exhibit enhanced input traits such as herbicide tolerance, insect resistance, and environmental stress tolerance (farmers are the direct beneficiaries). Second-generation GM crops possess added-value output traits such as nutrient enhancement for animal feed (consumers are the direct beneficiaries). Third-generation GM crops have the potential to produce pharmaceutical substances (also known as pharming), improve the production of biofuels, and produce products beyond traditional foods and fibers. Higher yield expectations and input costs savings from reduced use of agrochemicals have been the main factors behind the high adoption rate of firstgeneration GM crops by US farmers.

From a socio-economic point of view, researchers have spent a considerable amount of time trying to understand consumer perceptions and attitudes toward GM foods. The body of research carried out on the topic can be classified into four main groups (Ganiere, Chern, and Hahn 2006). The first group includes qualitative and descriptive analyses of consumer attitudes toward GM foods; results show that consumers tend to be more supportive when tangible benefits (such as the requirement for less inputs) are associated with GM foods. The second group is characterized by studies assessing consumer attitudes or behavioral intentions toward GM foods; risk and/or benefit perception and demographic variables were used to explain consumer attitudes or willingness-to-pay (WTP) for GM foods. The third group (the most published type) measures the WTP for GM foods versus non-GM foods; results of these studies show that, in certain circumstances, consumers are willing to pay premiums for non-GM foods, mainly organics. The fourth group is focused on the impact of information on consumer WTP for GM foods; studies often use experimental auction methods that tend to have small sample groups, limiting the validity of inferences about the population.

Because of the exploratory character of this article, we focus on the first three groups as they are related to the descriptive analysis of consumer attitudes toward GM foods; the factors related to behavioral intentions toward GM foods; and the price differential between GM food and non-GM food products, respectively.

\section{World Situation}

Commercial cultivation of GM crops began in 1996 and has been expanding ever since. Between 2001 and 2011, the global GM crop area increased at an annual rate of 20.41 percent, from 52.6 million hectares $(\mathrm{MH})$ to 160 million hectares, representing about 8.65 percent of the total global crop area of 1.84 billion hectares that year (FAOSTAT 2013). In 2011, about 29 countries cultivated biotech crops, with the United States being the leading world producer of GM crops, with the cultivation of $69 \mathrm{MH}$, or about 43.1 percent of the global GM production area, followed by Brazil (30.3 MH, 18.93\%); Argentina (23.7 MH, 14.81\%); India (10.6 MH, 6.62\%); and Canada (10.4 MH, 6.50\%) (ISAAA 2011). Together, these five countries account for 90 percent of the total area under GM cultivation (Figure 1).

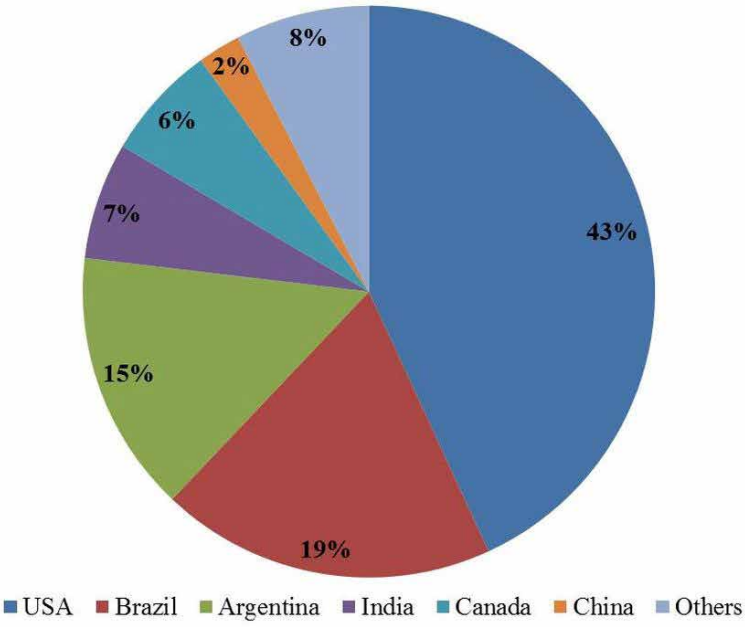

Figure 1. GM crops: Global area, by country, 2011 (\%). Source: ISAAA (2011).

In terms of area cultivated, the main GM crops are soybean, maize, cotton, and canola, respectively. Historically, soybean has been the dominant biotech crop cultivated; its harvested area has grown at an annual rate of 12.6 percent, 
from 33.3 MH in 2001 to $75.4 \mathrm{MH}$ in 2011. Biotech maize follows in importance, growing at an annual rate of 42 percent, from 9.8 MH in 2001 to $51 \mathrm{MH}$ in 2011. Next is biotech cotton, growing at an annual rate of 26.3 percent, from 6.8 MH in 2001 to $24.7 \mathrm{MH}$ in 2011. Finally, GM canola has expanded at an annual rate of 20.4 percent, from 2.7 MH in 2001 to 8.2 MH in 2011 (Figure 2). Other important GM crops include sugar beet, alfalfa, papaya, squash, poplar, tomato, sweet pepper, and potato, which together account for about $0.7 \mathrm{MH}(1 \%)$ of the total area under GM crop cultivation (ISAAA 2011).

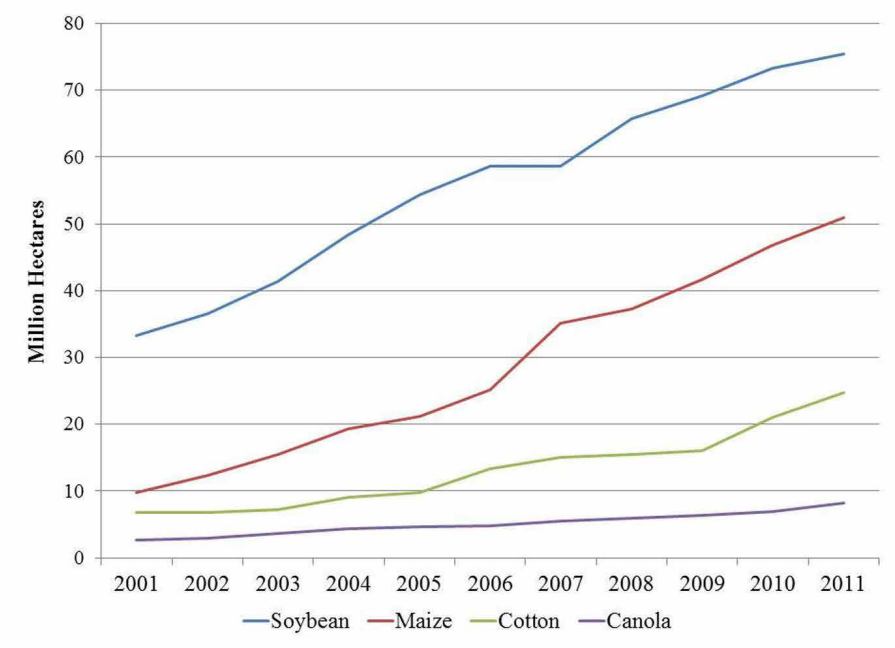

Figure 2. GM crops: Global area, by crop, 2001-2011 (million hectares $[\mathrm{MH}]$. Source: ISAAA (various years).

When considered from an adoption rate perspective, biotech cotton is the global leading crop, followed by soybean, maize, and canola. As illustrated in Figure 3, in 2011 , biotech cotton (24.7 MH) accounted for 82 percent of the global area of harvested cotton, followed by biotech maize (32\%), biotech canola (26\%), and biotech soybean (25\%), respectively (ISAAA 2011).

Researchers have found that biotech crops reduce the environmental impact of agriculture, and pose low risk to the health of consumers. Brookes and Barfoot (2006) estimated a global reduction in pesticide application of about 224 million kilograms of pesticide active ingredients because of GM crops cultivation from 1996 to 2005.

Allergenicity and toxicity of GM crops have been a controversial issue. Fermin et al (2011) found that GM Hawaiian papaya consumption does not pose any health risk because no allergenic or toxic products were found after simulating the human digestion process.

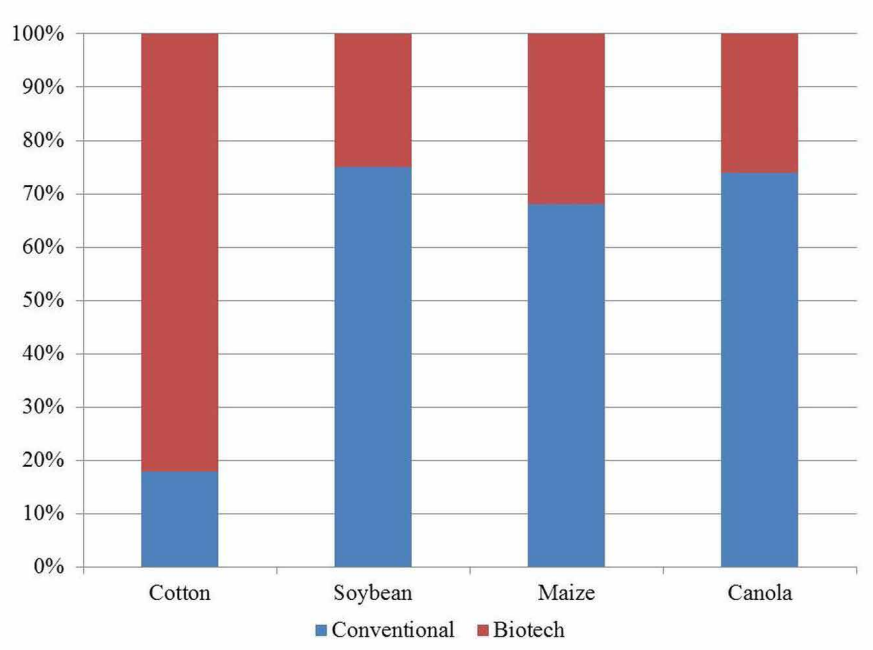

Figure 3. GM crops: Global adoption ratae, by crop, 2011 (\%).. Source: ISAAA (2011).

Biotech crops are considered the fastest solution to alleviate hunger and malnutrition in developing countries. For example, "golden rice" (a GM rice variety) is reported to produce and accumulate pro-vitamin A ( $\beta$-carotene ) in the grain (Goldenrice.org 2013). GM crops may play an important role to mitigate the effects of global climate change; bio-engineering crops with increased tolerance to drought might meet food demands where water is a constraint (ISAAA 2008).

Notwithstanding, biotech-derived food is considered a controversial issue, prompting government agencies of some developed countries, including some of the EU state members, Japan, Australia, Brazil, Russia, and China, to implement legislation mandating the labeling f GM food products (Justlabelit.org 2012). However, in practice, GM labeling is still a challenge because there are no consistent and harmonized sets of rules. Different industries, governments, and trade associations have developed their own standards, posing additional obstacles for the international trade of food products.

Consumer acceptance of GM foods around the world differs greatly, with the strongest opposition coming from the European Union. Results of the 2010 Eurobarometer survey on life sciences and biotechnology shows that a significant amount of the EU-27 population does not have a positive view about GM food; the survey showed that more than half (61\%) of the survey respondents oppose, less than one-fourth (23\%) are supporters, and the remaining (16\%) are undecided about this technology. There is no unified position within the European Union toward GM crops, as the individual member states have the legal right to decide whether or not to cultivate GM crops. Currently, five 
countries (Spain, Portugal, the Czech Republic, Romania, and Slovakia) grow GM crops (Gaskell et al 2010). Only two GM crops, corn and potatoes, have received formal approval in the European Union for cultivation.

Despite a high level of awareness toward biotechnology, support for biotech-derived food products in Japan is also low. A survey conducted in 2000 found that about 97 percent of the respondents knew about crop biotechnology-the highest level reported in the world. The survey found that consumers with a positive view about GM food represented only 31 percent of the respondents; consumer acceptance of GM pest-resistant crops was 33 percent; and 20 percent of the respondents were willing to buy GM fruits with a better taste (Macer and Cheng-Ng 2000).

In contrast to the EU and Japanese situations, about half of Chinese urban consumers (47\%) found biotech foods to be strongly or relatively acceptable, while between 5 and 15 percent of urban consumers were strongly or relatively opposed to biotech foods. Chinese consumers who had either a neutral opinion or could not specify their attitudes made up about one-third of the respondents. The survey also found a low level of awareness about biotech foods; three-quarters of the consumers surveyed had little to no knowledge about biotech foods (Lin et al. 2004). The low level of awareness toward biotech food may be one of the reasons behind the relatively high acceptance of it in China.

\section{US Situation}

\section{Brief Overview of US GM Food Production, Trade, and Regulatory Framework}

Before discussing consumer attitudes toward biotech products, it is important to provide a general overview about the current US GM food production, trade, and regulatory framework for biotech products. The United States is the largest world producer of GM crops. In 2011, the United States accounted for about 43.1 percent of the global biotech crop cultivated area (69 MH). Biotech crops grown in the United States include corn, soybean, cotton, canola, sugar beet, alfalfa, papaya, and squash (ISAAA 2011).

Exports are an important source of income for US agricultural commodity producers. One example of how the GM controversy affects US crops is the EU opposition to GM foods. Exported varieties of US corn are covered by a "de facto" GM import ban. A ruling of the World Trade Organization in 2006 stated that GM food import prohibitions by six of the EU countries (Austria, France, Germany,
Greece, Italy, and Luxembourg) violated the WTO's agreement on Sanitary and Phytosanitary (SPS) measures, which require such trade restrictions to be based on science and risk assessment (Hanrahan 2010). In spite of the WTO ruling, the six EU countries continue to maintain bans on GM crops using the WTO safeguard clause. Exports of US corn and soybeans to other major trading partners, such as China and Canada, have not faced any significant resistance on the GM crop issue.

A 2006 study (Heslop 2006) found that that about 60-70 percent of processed foods sold by supermarkets in North America contain some ingredients derived from GM crops, primarily corn, soy, and canola. This percentage is likely to be much higher in the United States because of the higher adoption rate of biotech varieties of corn and soybean grown there. For crop year 2012, it was reported that about 88 percent of all the corn and 93 percent of all the soybeans grown in the United States came from biotech varieties (USDA/ERS 2012).

Many US consumers are unaware of the GM ingredient content in processed foods because federal regulations do not require disclosure of this information. In 1992, the US Food and Drug Administration (FDA) published its "Statement of Policy: Foods Derived from New Plant Varieties" (FDA 1992). The policy states that the FDA has no basis for concluding that bioengineered foods differ from other foods in any meaningful or uniform way, or that, as a class, foods developed by the new techniques present any different or greater safety concern than foods developed by traditional plant breeding (Federal Register 1992). In January 2001, the FDA provided guidance for industry voluntary labeling indicating whether or not foods are developed using bioengineering (FDA 2001).

In November 2012, California voters rejected Proposition 37 (California Right-to-Know Genetically Engineered Food Act). In brief, had this proposition passed, it would have required food labels for all GMOs and food containing GM ingredients. Opponents of California's Proposition 37 argued that there was no scientific evidence against GM foods and that it would cost the average California family up to $\$ 400$ per year in higher grocery costs. In addition, the opponents pointed out that enforcing the regulation would cost taxpayers millions of dollars in special interest exemptions and shakedown lawsuits that would enrich trial lawyers (Noprop37.com 2012). Supporters of Proposition 37 claimed that it would help consumers to make informed choices about the food they eat and to question the lack of long-term health studies about the safety of GMOs, the link between GM crops and environmental problems, and the 
economic dispute over the extra costs associated with GMO labeling (Carighttoknow.org 2012).

\section{US Consumer Attitudes toward Biotech Food}

An insight into US consumer attitude toward GM food commodities can be gleaned from a survey conducted by Hallman et al. (2003). Among other things, the authors found that most Americans were not fully aware of GM foods because only about 12 percent of the respondents knew a lot about food biotechnology, as opposed to 45 percent knowing something and 43 percent knowing nothing about the subject. The survey also found that about 68 percent of the respondents had never been engaged in in any discussion about GM foods, 26 percent of the respondents did not know whether or not they had ever eaten GM food, and almost 50 percent were unaware that food products made with GM-derived ingredients are currently on supermarket shelves.

\section{A 2006 Pew Research Initiative survey (Organic and}

Non-GMO Report 2007) regarding US consumer awareness and understanding of biotech foods reported a 10 percent increase in net perception of biotech food product safety, compared with earlier studies. Among other things, the 2006 study reported that 45 percent of Americans felt more felt more comfortable about the safety of biotech food products, compared with only 29 percent who thought they were unsafe. Of interest was the finding that Americans were willing to change their opinions once provided with additional information about biotech food products being produced or manufactured using biotechnology.

An earlier study carried out by Baker and Burnham (2001), aimed at valuing different factors influencing consumer perception and valuation of GM corn flakes, found that opinions and risk aversions to GM foods were strong indicators of consumer acceptance or rejection for GM corn flakes, compared to socioeconomic variables such as income, education, and race. Their findings suggest that consumer behavior is determined mainly by what consumers believe, and to a lesser extent by how much they know about GM food products. The authors concluded that marketing efforts should focus on differentiating GM foods based on beneficial characteristics desired by consumers.

Another study considering consumer demand and attitude toward agro-biotechnology in both the United States and the United Kingdom was conducted by Moon and Balasubramanian (2002). They estimated consumer WTP for a breakfast cereal made of non-GM ingredients. The researchers found that US consumers were less likely to pay a premium for non-biotech breakfast cereal when they perceive biotech crops as beneficial based on reduced use of chemicals, increased food supply, or improved nutritional quality. Their findings suggest that efforts to change consumer perception about biotech food should address risk perception factors and promote the beneficial effects of biotech crops.

Researchers have put considerable effort into an attempt to measure consumers WTP for GM compared to non-GM food products. Li et al (2004) addressed the valuation and acceptance of GM corn-fed beef among US Pacific Northwest consumers with two information treatments. The first treatment found no genetic problems in GM corn-fed beef, with the findings providing positive information of GM corn because it requires less pesticide application. The second treatment findings did not provide any information. Results indicate that for the first group, the mean WTP to buy GM corn-fed beef is a 6 percent premium, while the second group required a mean 23 percent discount.

\section{Biotechnology Saved the Hawaiian Papaya Industry}

So far, the discussion has focused on GM developments, consumer's attitudes toward the GM crops across the globe, and the US consumer perception and behavior about GM crops. However, it is also important to mention a successful case of how, after following stringent scientific protocols and testing, a GM-derived biotech crop overcame the Japanese government concerns to be allowed to enter the Japan market.

Hawaii is the only US state where GM papayas are grown on a commercial scale. In 1911, a small-sized papaya cultivar called 'Solo' (about 2 pounds), with yellow flesh and very sweet taste, was introduced in Hawaii. The Solo cultivar was a huge success; by 1936, it was the only cultivar grown commercially in Hawaii. Later, in 1950, an outbreak of the papaya ringspot virus (PRSV) caused substantial economic losses to the Hawaiian papaya industry. As a result, papaya production moved to the Puna area of the Big Island. Despite the intense efforts of the Hawaii Agriculture Department, the disease continued to spread, eventually reaching the Puna area. Because of the importance of papaya as a source of export revenue for Hawaii's economy, work to develop a virus-resistant transgenic papaya began in 1986. By 1992, a field trial identified the transgenic line 55-1, which was resistant to PRSV under field conditions. From line 55-1, the transgenic PRSV resistant cultivars 'SunUp' and 'Rainbow' were developed. However, the 
disease continued to expand and, by 1997 , papaya production declined to an historical low of 38.8 million pounds, down from a high of 80.5 million pounds in 1984 .

After a regulatory review was undertaken by several federal agencies, in 1998, the Hawaii Papaya Administrative Committee obtained the licenses to commercialize the transgenic papaya seeds which were distributed among the interested growers. The transgenic cultivars reinvigorated the Hawaiian papaya industry and, in 2001, production recovered, reaching 55 million pounds, with an estimated farm gate value of $\$ 14.6$ million. However, the new GM Hawaiian papaya cultivars still had to overcome consumer acceptance in international markets, as well as in the continental United States. Canada and Japan have been the main export markets for Hawaiian papaya. Canada, which initially had some concerns about the Hawaiian GM papaya, quickly approved imports of the GM papaya in 2003. Canadian regulation does not require labeling for GM products; their supermarkets prohibit suppliers from labeling their products as GMO-free (Pesante 2003). Recently, there have been efforts to introduce a national standard for voluntary labeling (CBAN 2012).

In contrast, the Japanese government immediately banned Hawaiian GM papaya imports. As GM papaya production expanded, with a correspondent decline in production of non-GM fruit, Hawaiian exports of the non-GM fruit to that country fell sharply from $\$ 10.3$ million in 1998 to only $\$ 1.2$ million in 2011. One of the concerns for the Japanese was the allergenicity of the Hawaiian GM 'Rainbow' and 'SunUp' papaya cultivars, so a study was conducted by Fermin et al. (2011). Results of this study indicate that that the transgenic 'Rainbow' and 'SunUp' papaya cultivars do not pose a risk of food allergy. After a long regulatory review process, the Japanese government lifted the ban in December 2011 to allow imports of GM papaya from Hawaii. Japan mandates the labeling of all biotech-derived products; in compliance with regulations, the Hawaii Papaya Industry Association agreed to individual fruit labeling to prevent unintentional commingle with the nonGM papaya (USDA/FAS GAIN 2011). As stated before, the United States does not mandate labeling of biotech-derived products; consequently, Hawaiian GM papayas sold on the US mainland are not required to be labeled.

\section{Conclusions}

Biotechnology has now emerged as one of the most innovative technologies of modern times; this new technology is capable of improving a range of crops, including fruits, vegetables, and plantation crops, with greater precision while dealing with global challenges such as climate change. With more than 30 commercial GM crops grown on almost 160 million hectares in 29 countries and the expectation that there will be around 120 GM crops by 2015 , it is clear that agro-biotechnology is growing.

Several scientific studies have concluded that GM crops are safe, and that there is much to be gained from embracing the technology, which is fast becoming conventional in North America, South America, Asia, and Africa. Although the United States continues to remain the largest producer and consumer of biotech food and food products, followed by countries such as Brazil, Argentina, and India, it is clear that biotechnology will be of tremendous benefit to both developed and developing countries. Consumers will benefit from the assurance of available, cheap, wholesome food, while producers will benefit by engaging in viable farming operations that would be impossible without biotechnology.

While it is true that consumer attitudes toward GM foods vary widely across the world, it is also fair to note that public opinion is moving slowly toward acceptance of biotech foods. With a global population nearing 9 billion people, biotech crops offer a tremendous potential to mitigate threats of hunger and some of the adverse impacts of climate changes. Recent studies have shown that consumers are willing to accept biotech foods when provided with additional information on the safety of such products. While international trade issues related to biotech food products will arise based on individual laws and regulations, efforts are underway toward reaching a unified position regarding biotech labeling policies around the planet.

Better information about biotechnology and biotech-derived food products is needed. This bodes well for research at various institutions, including the University of Florida, on advancing genetic bioengineering. In this regard, news of the soon-to-be-released new GM papaya ringspot virus cultivar currently being developed by the University of Florida Tropical Research and Education Center in Homestead is welcome to papaya growers in South Florida. With the new cultivar comes the hope that it will provide them with the arsenal to fight PRSV with a profitable alternative, leading to increased farm income and competitiveness.

\section{References}

Baker, G.A. and T.A. Burnham. 2001. Consumer response to genetically modified foods: Market segment analysis and implications for producers and policy makers. Journal of Agricultural and Resource Economics 26: 387-403. 
Brookes, G., and Barfoot, P. 2010. Global impact of biotech crops: Environmental effects, 1996-2008. AgBioForum 13(1):76-94.

Brookes, G. and Barfoot, P. 2006. Global impact of biotech crops: Socio-economic and environmental effects in the first ten years of commercial use. AgBioForum, 9(3):139-151.

Carighttoknow.org (California Right to Know). 2012. Get the Facts. http://www.carighttoknow.org/facts.

CBAN (Canadian Biotechnology Action Network). 2012. Resources: Labeling. http://www.cban.ca/Resources/Topics/ Labeling.

FAOSTAT 2013. Production data statistics: Crops. http://faostat.fao.org/site/567/DesktopDefault. aspx?PageID=567\# ancor.

FDA. 1992. Statement of Policy-Foods Derived from New Plant Varieties. United States Food and Drug Administration, Washington, D.C. http://www.fda.gov/Food/GuidanceRegulation/GuidanceDocumentsRegulatoryInformation/ Biotechnology/ucm096095.htm.

FDA. 2001. Guidance for Industry: Voluntary Labeling Indicating Whether Foods Have or Have Not Been Developed Using Bioengineering; Draft Guidance. United States Food and Drug Administration, Washington, D.C. http://www. fda.gov/Food/GuidanceRegulation/GuidanceDocumentsRegulatoryInformation/LabelingNutrition/ucm059098. htm.

Federal Register. 1992. Statement of Policy: Foods Derived from New Plant Varieties. Part IX (May 29) United States Department of Health and Human Services, Food and Drug Administration, Washington, D.C. Federal Register 57(104):22984-23005.

Fermin, G., R. Keith, J. Suzuki, S. Ferreira, D. Gaskill, K. Pitz, R. Manshardt, D. Gonsalves, and S. Tripathi. 2011. Allergenicity assessment of the papaya ringspot virus coat protein expressed in transgenic Rainbow papaya. Journal of Agricultural and Food Chemistry 59:10006-10012.

Gaskell, G., S. Stares, A. Allansdottir, N. Allum, P. Castro, Y. Esmer, C. Fischler, J. Jackson, N. Kronberger, J. Hample, N. Mejlgaard, A. Quintanilha, A. Rammer, G. Revuelta, P. Stoneman, H. Torgersen, and W. Wagner. 2010. Europeans and Biotechnology in 2010. Winds of Change?
Brussels: European Commission. http://ec.europa.eu/ public_opinion/archives/ebs/ebs_341_winds_en.pdf.

Ganiere, P., W. Chern, and D. Hahn. 2006. A continuum of consumer attitudes toward genetically modified foods in the United States. Journal of Agricultural and Resource Economics 31(1):129-149.

Goldenrice.org. 2013. Golden Rice Project: Golden Rice is part of the solution: Biofortified rice as a contribution to the alleviation of life-threatening micronutrient deficiencies in developing countries. http://www.goldenrice.org/.

Hallman, W.K., W.C. Hebden, H.L. Aquino, C.L. Cuite, and J.T. Lang, J.T. 2003. Public Perceptions of Genetically Modified Foods: A National Study of American Knowledge and Opinion. Food Policy Institute Report Number RR1003-004. Food Policy Institute, Rutgers University, New Brunswick, NJ. http://www.foodpolicy.rutgers.edu/docs/ pubs/2003_Public_Perceptions_of_Genetically_Modified_Foods.pdf.

Hanrahan, C. 2010. Agricultural biotechnology: The US-EU dispute. Congressional Research Service Reports 69. Washington, D.C.: CRS. http://digitalcommons.unl.edu/ crsdocs/69.

Heslop, L.A. 2006. If we label it, will they care? The effect of GM-ingredient labeling on consumer responses. Consumer Policy 29(2):203-228.

ISAAA. 2011. Global Status of Commercialized Biotech/GM Crops: 2011. 43-2011. ISAAA Briefs, International Service for the Acquisition of Agri-Biotech Applications (ISAAA), Manila, Philippines; Narobi, Kenya, Africa; Ithaca, New York, USA. http://www.isaaa.org/resources/publications/ briefs/43/executivesummary/default.asp.

ISAAA. 2008. Pocket K No. 32: Biotechnology for the Development of Drought Tolerant Crops. http://www.isaaa.org/ resources/publications/pocketk/32/default.asp.

ISAAA. Various Years. Data on GM crops, various years. ISAAA (International Service for the Acquisition of AgriBiotech Applications), Manila, Philippines; Narobi, Kenya, Africa; Ithaca, New York, USA.

James. C. 2008. Global Status of Commercialized Biotech/ GM Crops: 2011. 39-2008. ISAAA Briefs, International Service for the Acquisition of Agri-Biotech Applications (ISAAA), Manila, Philippines; Narobi, Kenya, Africa; 
Ithaca, New York, USA. http://www.isaaa.org/resources/ publications/briefs/39/download/isaaa-brief-39-2008.pdf.

Justlabelit.org (Just Label It). 2012. Right to Know. http:// justlabelit.org/right-to-know/.

Li, Q., McCluskey, J., and Wahl, T. 2004. Effects of information on consumers' willingness to pay for GM-corn-fed beef. Journal of Agricultural and Food Industrial Organization 2(2):Article 9.

Lin, W., A. Somwaru, F. Tuan, J. Huang, and J. Bai. 2004. Consumer attitudes toward biotech foods in China. Working paper, Economic Research Service, United States Department of Agriculture, Washington, D.C.

Macer, D. and M.A. Chen-Ng. 2000. Changing attitudes to biotechnology in Japan. Nature Biotechnology, 18(9):945-947.

Moon, W.K. and S.K. Balasubramanian. 2002. Public perceptions and willingness-to-pay a premium for non-GM foods in the US and UK. AgBio-Forum 4(3/4):221-231

(Article 10). http://www.agbioforum.org/v4n34/v4n34a10moon.htm or http://www.agbioforum.org/v4n34/v4n34a10moon.pdf.

Noprop37.com (No on 37). 2012. Stop the Deceptive Food Labeling Scheme. No on 37, Sacramento, CA. http://www. noprop37.com/.

Organic and Non-GMO Report. 2007. US consumers concerned about safety of GM foods. Organic and NonGMO Report (January). http://www.non-gmoreport.com/ articles/jan07/GM_food_safety.php.

Panos Media Briefing. 1999. Greed or Need? Genetically Modified Crops. PMB No. 30A. Panos Media Briefing, London, UK. http://www.ratical.org/co-globalize/GMcrops. html.

Pesante, A. 2003. Market Outlook Report: Fresh Papayas. Hawaii Department of Agriculture, Honolulu, HI. http:// hawaii.gov/hdoa/add/research-and-outlook-reports/ papaya\%20outlook\%20report.pdf.

Stein, A.J. and E. Rodriguez-Cerezo. 2010. Low-level presence of new GM crops: An issue on the rise for countries where they lack approval. AgBioForum 13(2):173-182.

USDA/ERS. 2012. Adoption of Genetically Engineered Crops in the United States. Economic Research Service, United
States Department of Agriculture, Washington, D.C. http:// www.ers.usda.gov/data-products/adoption-of-geneticallyengineered-crops-in-the-us.aspx.

USDA/FAS. 2011. Gain Report: Japan Approved GM papaya. Foreign Agricultural Service, United States Department of Agriculture, Washington, D.C. http://gain.fas.usda.gov/ Recent\%20GAIN\%20Publications/Japan\%20approved\%20 GM\%20papaya_Tokyo_Japan_12-19-2011.pdf. 